\title{
Accelerated Aging for the Evaluation of the Physiological Potential of Eggplant Seeds
}

\author{
Cristiane Deuner ${ }^{1}$, D. B. Rodrigues 2 , L. V. M. de Tunes ${ }^{2}$, A. S. Almeida ${ }^{2}$, A. S. Suñe ${ }^{2}$, A. B. N. Martins ${ }^{2}$, \\ Gustavo Zimmer ${ }^{2}$, Henrique Chagas ${ }^{2}$, Ewerton Gewehr ${ }^{2}$, L. H. Konzen ${ }^{2} \&$ B. B. Reis ${ }^{2}$ \\ ${ }^{1}$ IFSul Pelotas, Campus Visconde da Graça, RS, Brazil \\ ${ }^{2}$ Federal University of Pelotas, Capão do Leão, RS, Brazil \\ Correspondence: A. B. N. Martins, Federal University of Pelotas, Capão do Leão, RS, Brazil. E-mail: \\ amartinsfv@hotmail.com
}

Received: April 7, $2018 \quad$ Accepted: May 20, $2018 \quad$ Online Published: July 15, 2018

doi:10.5539/jas.v10n8p477 URL: https://doi.org/10.5539/jas.v10n8p477

\begin{abstract}
The use of healthy and vigorous seeds is necessary to ensure adequate plant stands, therefore, vigor tests are used to measure the physiological potential of seeds alongside with the germination test. The objective of this study was to evaluate different procedures for the estimation of the physiological potential of eggplant seeds through the accelerated aging test. Seed lots were tested for moisture content, germination, first count of germination, seedling emergence and speed of emergence index. Then, seeds were subjected to the conventional accelerated aging test, using an unsaturated $\mathrm{NaCl}$ solution or a $\mathrm{NaCl}$ saturated solution, for 24,48 and 72 hours at $41{ }^{\circ} \mathrm{C}$, estimating the moisture content after each period of aging. The treatments were allocated in a completely randomized design, with four treatments (seed lots) and four replicates. The use of the saturated solution of $\mathrm{NaCl}$ decreases the absorption of water and the rate of deterioration of eggplant seeds during the accelerated aging test, providing more uniform results. The accelerated aging test allows eggplant seed lots from cv. Napoli to be ranked at different levels of vigor and, among the procedures tested, the combinations $41{ }^{\circ} \mathrm{C} / 48$ hours and $41^{\circ} \mathrm{C} / 72$ hours allowed the proper assessment of the physiological potential of seeds of this cultivar.
\end{abstract}

Keywords: germination, saline solution, Solanum melongena L., vigor

\section{Introduction}

The eggplant (Solanum melongena L.) is a vegetable which belongs to the family Solanaceae, as well as tomatoes, paprika, pepper, potatoes and Jilo, the specie is originated in India and was introduced to Brazil in the 16th century by the Portuguese (Weber et al., 2010). The crop has a great economic importance, which is expanding due to alleged medicinal properties of the fruits, in particular, the reduction of cholesterol levels and blood pressure and also peculiar characteristics used in herbal diets, with relevant medicinal substances (Montemor \& Souza, 2009; Oliveira et al., 2013).

The evaluation of the physiological potential of seeds is an essential component of any quality control program, as it provides information for the detection and problem solving during the production process, as well as on seed performance (Costa et al., 2008). As the official procedure for evaluating the ability seeds to produce normal seedlings under ideal conditions, the germination test is conducted in the laboratory under favorable conditions of substrate, moisture and temperature. As a result, this test usually overestimates the physiological potential of seed lots, thus creating a need for improved testing techniques regarding seed vigor to provide consistent results in a short time (Pereira et al., 2011).

Vigor tests have been used to identify differences in the performance of seed lots, which may occur during storage or after seeding, highlighting lots with greater capacity to yield adequate stands under a wide range of environmental conditions, usually unfavorable (Marcos Filho et al., 2009), thus, providing complementary information to that provided by the germination test.

The accelerated aging test is one of the most commonly used procedures for the evaluation of seed vigor and has shown high correlation with the seedling emergence of several vegetable species in the field, i.e. broccoli, eggplant, coriander and parsley (Fessel et al., 2003; Torres \& Negreiros, 2008; Tunes et al., 2013). This test is based on the simulation of adverse environmental conditions such as high temperatures and high relative 
humidity, which are listed as the main factors responsible for seed deterioration (Guedes et al., 2009), wherein temperature and time of exposure will vary on their effects according to the different species.

Small-sized seeds, which are common for many vegetable species, imbibe and deteriorate more quickly, making it difficult to obtain reliable results in the accelerated aging test with water (Torres \& Marcos Filho, 2001). This has led to research replacing water by saturated salt solutions, without reducing the test's sensitivity (Jianhua \& McDonald, 1996). Some authors such as Ramos (2004) in rocket, were able to rank seed lots efficiently according to their levels of vigor through the accelerated aging test with the use of saturated salt solutions. However, Ribeiro and Carvalho (2005), found that saturated solutions of $\mathrm{NaCl}$ and $\mathrm{KCl}$ did not reduce the germination of carrot, lettuce and broccoli seeds until sufficient values to allow comparison between lots.

The objective of this work was to determine a suitable methodology for conducting the accelerated aging test in eggplant seeds.

\section{Materials and Methods}

The work was conducted at the Seed Laboratory from the Department of Plant Science at the Faculdade de Agronomia Eliseu Maciel of the Universidade Federal de Pelotas, Rio Grande do Sul, Brazil.

Four eggplant seed lots were tested for:

Moisture content (MC), for which two subsamples of each lot were dried at $105 \pm 3{ }^{\circ} \mathrm{C}$ for 24 hours, in compliance with the "Regras para análise de sementes"-Brazilian Rules for Seed Testing (BRST) (Brasil, 2009).

Germination $(\mathrm{G})$, four 50 -seed replicates were evenly arranged on foils of blotting paper, which was moistened with distilled water in a volume of 2.5 times the weight of the paper and placed into gerbox containers. The containers were placed into a germination chamber and kept at $25^{\circ} \mathrm{C}$, performing the first count at seven days and the final count after fourteen days, according to BRST (Brasil, 2009).

Seedling emergence (SE), normal seedling count was performed on the 14th day after sowing on four 50 -seed replicates each seed lot, distributed in Styrofoam trays filled with PLANTIMAX ${ }^{\circledR}$ commercial substrate for vegetables. The standard for normal seedlings was seedlings $\geq 1 \mathrm{~cm}$ in height.

Emergence speed index (ESI): carried out together with the SE test, with counts for emerged seedlings performed daily until stabilization on the fourteenth day after sowing.

After the initial evaluation of seed quality all seed lots were subjected to the accelerated aging test, in its conventional and modified versions, described as follows:

Conventional accelerated aging (CAA): seeds distributed uniformly on an aluminum screen within plastic gerbox containers, filled with $40 \mathrm{~mL}$ of water under the screen. The gerbox were kept in a BOD incubator during 24,48 and 72 hours at $41{ }^{\circ} \mathrm{C}$ and after each period of aging, the germination test was applied on four replicates of 50 seeds each lot, performing the count for normal seedlings on the seventh day after sowing; Accelerated aging with unsaturated saline solution (AAUS), performed in a similar way to AAC, however, adding to the bottom of the plastic box $11 \mathrm{~mL}$ of $\mathrm{NaCl}$ solution $(11 \mathrm{~g}$ of $\mathrm{NaCl}$ in $100 \mathrm{~mL}$ of water), thus creating an environment with a relative humidity of 94\%, adapting the methodology described by Jianhua and McDonald (1996), and Accelerated aging with saturated saline solution (AASS), similar to the methodology described for AAUS except for the concentration of the solution, which was of $40 \mathrm{~mL}$ of NaCl (40 g NaCl in $100 \mathrm{~mL}$ of water), creating an environment with a relative humidity of $76 \%$.

The data in percentage were transformed by arc $\sin \sqrt{\mathrm{X} / 100}$ before statistical analysis through the System of Statistical Analysis WinStat 1.0 (Machado \& Conceição, 2003). The experimental design was completely randomized and, when appropriate, treatment means were compared by Tukey test at $5 \%$ probability level, while Pearson correlation coefficients were compared at the $1 \%$ and $5 \%$ probability levels.

\section{Results and Discussion}

\subsection{Evaluation of Seed Quality}

The initial germination of the eggplant seed lots cv. Napoli used in the experiment was similar (Table 1), above the minimum required for the eggplant seed commerce which is of $70 \%$ (Brasil, 1986). The fact that no difference was observed on the germination values between seed lots is suitable for the use of vigor tests, since the main feature of the latter is to show differences in seed quality which are not detected by the germination test (Marcos Filho, 1999). The first count of the G test and ESI, showed seed lots 2 and 4 as those of superior quality. The ESI was efficient in ranking all lots, showing lot 4 with the highest quality, followed with decreasing vigor levels by lots 2, 1 and 3, respectively. According to Marcos Filho (1999), SE test is a good indicator of the 
efficiency of vigor tests to evaluate the physiological potential of seed lots. Test results from the initial stage of this research suggest that the efficiency to distinguish between high and low-vigor eggplant seed lots was higher for the SE and ESI tests.

Table 1. Seed quality of four eggplant cv. Napoli seed batches, assessed for germination (G), first count of germination (FC), seedling emergence (SE) and emergence speed index (ESI)

\begin{tabular}{lllll}
\hline Batches & G & FC & SE & ESI \\
\hline 1 & $89 \mathrm{~A}^{*}$ & $72 \mathrm{~B}$ & $69 \mathrm{~B}$ & $8,9 \mathrm{C}$ \\
2 & $90 \mathrm{~A}$ & $82 \mathrm{~A}$ & $80 \mathrm{~A}$ & $12,4 \mathrm{~B}$ \\
3 & $89 \mathrm{~A}$ & $72 \mathrm{~B}$ & $63 \mathrm{C}$ & $7,4 \mathrm{D}$ \\
4 & $92 \mathrm{~A}$ & $77 \mathrm{~A}$ & $13,7 \mathrm{~A}$ & \\
CV $(\%)$ & 2.2 & 3.7 & 3.1 & 2.6 \\
\hline
\end{tabular}

Note. * Means followed by the same letter in the column do not differ by Tukey test at 5\% probability.

\subsection{Moisture Content}

The average results for the initial moisture content and after CAA are presented in Table 2. These data were not analyzed statistically and wereonly used for seed lot characterization, after the completion of the conventional accelerated aging test. Results for the moisture content were similar across seed lots, ranging between $7.8 \%$ and $8.3 \%$.

The eggplant seeds showed increases in their moisture content as the aging periods increased for all of the accelerated aging methods tested (Table 2). However, the use of a $\mathrm{NaCl}$ saturated solution (AASS) promoted the greater reduction in the speed of moisture uptake by eggplant seeds during the aging period, when compared with the unsaturated method (AAUS).

The use of the saturated saline solution causes a decrease in the relative moisture in the interior of the plastic boxes $(76 \%)$ when compared to AAUS, consequently, seed hydration may occur at slower rates, i.e. the absorption of water by the seed is delayed, as suggested by Jianhua and McDonald (1996). Also, enhanced uniformity in the moisture levels among the four seed lots was evident for the AASS method.

Table 2. Seed moisture content (\%) of four eggplant seed batches from cv. Napoli, at the beginning of the experimental period and after completion of different periods treated to conventional accelerated aging (AAC), an unsaturated $\mathrm{NaCl}$ solution (AAUS) and with a saturated $\mathrm{NaCl}$ solution (AASS)

\begin{tabular}{|c|c|c|c|c|c|c|c|c|c|c|}
\hline \multirow{2}{*}{ Batches } & \multirow{2}{*}{ Start } & \multicolumn{3}{|c|}{$\mathrm{AAC}$} & \multicolumn{3}{|c|}{ AAUS } & \multicolumn{3}{|c|}{ AASS } \\
\hline & & $24 \mathrm{~h}$ & $48 \mathrm{~h}$ & $72 \mathrm{~h}$ & $24 \mathrm{~h}$ & $48 \mathrm{~h}$ & $72 \mathrm{~h}$ & $24 \mathrm{~h}$ & $48 \mathrm{~h}$ & $72 \mathrm{~h}$ \\
\hline 1 & 8.3 & 15.2 & 23.0 & 34.7 & 12.9 & 19.5 & 23.0 & 11.6 & 12.3 & 12.3 \\
\hline 2 & 8.1 & 18.9 & 30.0 & 39.3 & 11.4 & 16.3 & 25.1 & 10.6 & 12.0 & 12.3 \\
\hline 3 & 8.2 & 11.9 & 17.7 & 24.6 & 15.6 & 21.5 & 27.4 & 12.2 & 13.0 & 13.4 \\
\hline 4 & 7.8 & 21.0 & 29.9 & 42.0 & 10.6 & 14.3 & 21.2 & 10.3 & 11.0 & 11.1 \\
\hline
\end{tabular}

\subsection{Accelerated Aging Test}

A closer look at the results of the accelerated aging test (Table 3 ) reveals that all methods and aging periods were able to separate the seed lots on at least two levels of vigor. Exposure for 72 hours at $41{ }^{\circ} \mathrm{C}$, i.e. the standard method, proved to be more efficient in the ranking of lots on the basis of their physiological potential, while complying with the results of the SE test, showing eggplant seed lots 2 and 4 with the highest vigor and 3 with the lowest. However, this period of exposure caused significant reduction on seed germination, yielding similar results to those reported by Ramos et al. (2004), Tunes et al. (2009), Radke et al. (2016) in seeds of rocket, barley and coriander, respectively.

Seeds subjected to accelerated aging for 24 hours at $41^{\circ} \mathrm{C}$ (AAC), were also ranked into four levels of vigor, in a similar fashion to the 72-hour period. Although vigor values differed somehow to those of SE, this method may be suitable to assess the vigor of cv. Napoli eggplant seed lots, since two days less are necessary when compared 
to the method of 72 hours at $41^{\circ} \mathrm{C}$. Similar results were found in lettuce (Santos et al., 2011) and broccoli (Lopes \& Mauri, 2012), where the conventional accelerated aging test was efficient to evaluate seed vigor.

According to Fessel et al. (2005), the use of a $\mathrm{NaCl}$ saturated solution in seeds of broccoli provided a lower and more uniform moisture content at the end of the aging periods, an advantage for the use of this procedure in relation to that with water. The latter stems from causing a lower rate of seed deterioration, thus yield ingless extreme results, more uniform and better correlated to the SE test. Similar results for melon seeds were reported by Torres and Marcos Filho (2003).

Bhering et al. (2006) found that, regardless of the relative air humidity inside the plastic boxes, the accelerated aging test was effective in the evaluation of the vigor of pepper seeds, yielding results similar to those obtained in the first count and germination at low temperature. However, Torres and Negreiros (2008) in eggplant seeds of $\mathrm{cv}$. Embu; found that in spite of the accelerated aging test, using the procedure $41{ }^{\circ} \mathrm{C} / 48$ hours, was able to rank different seed lots according to their vigor levels, the procedure was considered not sufficiently consistent.

Table 3. Germination (\%) of four seed batches of eggplant, cv. Napoli, after completion of different periods treated to conventional accelerated aging (AAC), an unsaturated $\mathrm{NaCl}$ solution (AAUS) and with a saturated $\mathrm{NaCl}$ solution (AASS)

\begin{tabular}{|c|c|c|c|c|c|c|c|c|c|}
\hline \multirow{2}{*}{ Batches } & \multicolumn{3}{|c|}{$\mathrm{AAC}$} & \multicolumn{3}{|c|}{ AAUS } & \multicolumn{3}{|c|}{ AASS } \\
\hline & $24 \mathrm{~h}$ & $48 \mathrm{~h}$ & $72 \mathrm{~h}$ & $24 \mathrm{~h}$ & $48 \mathrm{~h}$ & $72 \mathrm{~h}$ & $24 \mathrm{~h}$ & $48 \mathrm{~h}$ & $72 \mathrm{~h}$ \\
\hline 1 & $77 \mathrm{~B}^{*}$ & $52 \mathrm{C}$ & $49 \mathrm{~B}$ & $84 \mathrm{~B}$ & $80 \mathrm{~A}$ & $73 \mathrm{~B}$ & $82 \mathrm{~B}$ & $79 \mathrm{BC}$ & $76 \mathrm{~B}$ \\
\hline 2 & $81 \mathrm{~A}$ & $71 \mathrm{~A}$ & $58 \mathrm{~A}$ & $82 \mathrm{~B}$ & $81 \mathrm{~A}$ & $75 \mathrm{~B}$ & $85 \mathrm{AB}$ & $83 \mathrm{AB}$ & $78 \mathrm{AB}$ \\
\hline 3 & $68 \mathrm{C}$ & $53 \mathrm{C}$ & $30 \mathrm{C}$ & $75 \mathrm{C}$ & $67 \mathrm{~B}$ & $64 \mathrm{C}$ & $81 \mathrm{~B}$ & $78 \mathrm{C}$ & $76 \mathrm{~B}$ \\
\hline 4 & $79 \mathrm{AB}$ & $67 \mathrm{~B}$ & $57 \mathrm{~A}$ & $88 \mathrm{~A}$ & $83 \mathrm{~A}$ & $81 \mathrm{~A}$ & $88 \mathrm{~A}$ & $85 \mathrm{~A}$ & $81 \mathrm{~A}$ \\
\hline $\mathrm{CV}(\%)$ & 2.9 & & & & & & & & \\
\hline
\end{tabular}

Note. * Means followed by the same letter in the column do not differ by Tukey test at 5\% probability.

\subsection{Analysis of the Correlation}

The analysis of the correlation coefficients between the tests of germination and vigor assessed in this study (Table 4) showed a significant correlation between the G and the AAUS tests $(\mathrm{r}=0.531)$ for the 24-hour period, however, this same correlation for the 72-hour period, whether in the AAC $(r=0.516)$ or the AASS $(r=0.507)$ procedures, was also significant.

Similar results were reported by Lopes et al. (2010) in seeds of okra, who observed that the accelerated aging for 72 hours at $41^{\circ} \mathrm{C}$ allowed greater sensitivity for the ranking of seed lots in different levels of quality.

In the test with the first count of germination, significant correlations with vigor tests were found for all periods of accelerated aging, being that for the 24-hour period only the AAC treatment $(r=0.610)$ yielded a significant correlation. However, for the rest of the aging periods significant correlations were found for all the accelerated aging methods tested (Table 4).

The correlation estimated between the tests of seedling emergence (SE) and the emergence speed index (ESI) with the accelerated aging test was significant for the different aging periods and methods evaluated. This result suggests that the accelerated aging test is appropriate to evaluate the physiological potential of seeds, since a positive, significant correlation was calculated with the tests of SE and ESI. Since the latter are carried out in the field, the consistency for the classification of seed lots is enhanced. As for the seed moisture content (Table 4), no significant correlation was found for the different tests of accelerated aging, with the exception of the 48-hour period of the AASS treatment $(\mathrm{r}=0.581)$. 
Table 4. Pearson's correlation coefficient (r) between the results of the tests of germination (G), first count of germination (FC), seedling emergence (SE), emergence speed index (ESI) and moisture content (MC) with the tests of conventional accelerated aging (AAC), with an unsaturated $\mathrm{NaCl}$ solution (AAUS) and with a saturated $\mathrm{NaCl}$ solution (AASS), performed on seeds of eggplant cv. Napoli after 24, 48 and $72 \mathrm{~h}$ of exposure to accelerated aging treatments

\begin{tabular}{lllllll}
\hline & & $\mathrm{G}$ & $\mathrm{FC}$ & $\mathrm{SE}$ & $\mathrm{ESI}$ & $\mathrm{MC}$ \\
\hline $24 \mathrm{~h}$ & AAC & $0.474 \mathrm{~ns}$ & $0.610 * *$ & $0.881 *$ & $0.801 *$ & $0.244 \mathrm{~ns}$ \\
& AAUS & $0.531 * *$ & $0.286 \mathrm{~ns}$ & $0.619 * *$ & $0.745 *$ & $0.408 \mathrm{~ns}$ \\
& AASS & $0.320 \mathrm{~ns}$ & $0.452 \mathrm{~ns}$ & $0.641 *$ & $0.804 *$ & $0.414 \mathrm{~ns}$ \\
\hline $78 \mathrm{~h}$ & AAC & $0.469 \mathrm{~ns}$ & $0.766^{*}$ & $0.861 *$ & $0.868 *$ & $0.169 \mathrm{~ns}$ \\
& AAUS & $0.384 \mathrm{~ns}$ & $0.504 * *$ & $0.756 *$ & $0.792 *$ & $0.469 \mathrm{~ns}$ \\
$72 \mathrm{~h}$ & AASS & $0.291 \mathrm{~ns}$ & $0.558 *$ & $0.611 * *$ & $0.831 *$ & $0.581 * *$ \\
& AAC & $0.516 * *$ & $0.773 *$ & $0.947 *$ & $0.958 *$ & $0.287 \mathrm{~ns}$ \\
& AAUS & $0.372 \mathrm{~ns}$ & $0.542 * *$ & $0.750 *$ & $0.857 *$ & $0.427 \mathrm{~ns}$ \\
\hline
\end{tabular}

Note. ${ }^{\text {ns }}$ not significant; $*$ significant at the $5 \%$ level; ${ }^{* *}$ significant at the $1 \%$ level probability.

\section{Conclusion}

The accelerated aging test for the combinations of $41{ }^{\circ} \mathrm{C} / 48$ hours and $41{ }^{\circ} \mathrm{C} / 72$ hours allows the sorting of eggplant seed lots in different levels of vigor.

The use of a saturated solution of $\mathrm{NaCl}$ in the aging chamber decreases the rate of water absorption and thus, the rate of deterioration of eggplant seeds during the accelerated aging test, enhancing the uniformity of results.

\section{References}

Bhering, M. C., Dias, D. C. F. S., Vidigal, D. S., \& Naveira, D. S. P. (2006). Teste de envelhecimento acelerado em sementes de pimenta. Revista Brasileira de Sementes, 28(3), 64-71. https://doi.org/10.1590/S0101-3122 2006000300010

Brasil. (1986). Portaria $n^{o}$. 457, de 18 de dezembro de 1986 (Estabelece os padrões de sementes olerícolas para distribuição...) (p. 19653). Diário Oficial da União, Poder Executivo, Brasília, DF.

Brasil. (2009). Rules for seed analysis (p. 395). Ministry of Agriculture, Livestock and Food Supply, Secretaria de Defesa Agropecuária. Brasília, DF: Mapa/ACS.

Costa, C. J., Trzeciak, M. B., \& Villela, F. A. (2008). Potencial fisiológico de sementes de brássicas com ênfase no teste de envelhecimento acelerado. Horticultura Brasileira, 26, 144-148. https://doi.org/10.1590/ S0102-05362008000200003

Fessel, S. A., Silva, L. J. R., Galli, J. A., \& Sader, R. (2005). Uso de solução salina (NaCl) no teste de envelhecimento acelerado em sementes de brócolis (Brassica oleracea L. var. italica Plenk). Científica, 33(1), 27-34. Retrieved from https://www.researchgate.net/publication/27717138

Guedes, R. S., Alves, E. U., Gonçalves, E. P., Viana, J. S., Bruno, R. L. A., \& Colares, P. N. Q. (2009). Resposta fisiológica de sementes de Erythrina velutina Willd. ao envelhecimento acelerado. Semina Ciências Agrárias, 32(2), 323-330. https://doi.org/10.5433/1679-0359.2009v30n2p323

Jianhua, Z., \& McDonald, M. B. (1996). The saturated salt accelerated aging test for small seed crops. Seed Science and Technology, 25, 123-131.

Lopes, J. C., \& Mauri, J. (2012). Qualidade física e fisiológica de sementes de brócolos biológicos e convencionais. Revista de Ciências Agrárias, 35(19), 193-201.

Lopes, M. M., Sader, R., Paiva, A. S., \& Fernandes, A. C. (2010). Teste de envelhecimento acelerado em sementes de quiabo. Bioscience Journal, 26(4), 491-501.

Machado, A., \& Conceição, A. R. (2003). Programa estatístico WinStat: Sistema de análise estatístico para Windows. Pelotas, RS. 
Marcos Filho, J., Kikuti, A. L. P., \& Lima, L. B. (2009). Métodos para avaliação do vigor de sementes de soja, incluindo análise computadorizada de imagens. Revista Brasileira de Sementes, 31(1), 102-112. https://doi.org/10.1590/S0101-31222009000100012

Marcos Filho, J., Krzyzanowski, F. C., \& Vieira, R. D. (1999). Teste de envelhecimento acelerado. In J. B. França Neto (Ed.), Vigor de sementes: conceitos e testes (Chap. 3, pp. 1-24). Londrina: ABRATES.

Montemor, K. A., \& Souza, D. T. M. (2009). Biodiversidade de polinizadores e biologia floral em cultura de berinjela (Solanum melongena). Zootecnia Tropical, 27(1), 97-103.

Nakagawa, J. (1999). Testes de vigor baseados no desempenho das plântulas. In F. Krzyzanowski, R. D. Vieira, \& J. B. França-Neto (Eds.), Vigor de sementes: Conceitos e testes (Cap. 2, pp. 2-24). Londrina: ABRATES.

Oliveira, F. A., Medeiros, J. F., Alves, R. C., Linhares, P. S., Medeiros, A. A., \& Oliveira, M. K. T. (2014). Interação entre salinidade da água de irrigação e adubação nitrogenada na cultura da berinjela. Revista Brasileira de Engenharia Agricola e Ambiental, 18(5), 480-486. https://doi.org/10.1590/S1415-43662014 000500003

Pereira, M. F. S., Torres, S. B., Linhares, P. C. F., Paiva, A. C. C., Paz, A. E. S., \& Dantas, A. H. (2011). Qualidade fisiológica de sementes de coentro [Coriandrum sativum (L.)]. Revista Brasileira de Plantas Medicinais, 13, 518-522. https://doi.org/10.1590/S1516-05722011000500002

Radke, A. K., Reis, B. B., Gewehr, E., Almeida, A. S., Tunes, L. M., \& Villela, F. A. (2016). Alternativas metodológicas do teste de envelhecimento acelerado em sementes de coentro. Ciência Rural, 46(1), 95-99. https://doi.org/10.1590/0103-8478cr20140188

Ramos, N. P., Flor, E. P. O., Mendonça, E. A. F., \& Minami, K. (2004). Envelhecimento acelerado em sementes de rúcula (Eruca sativa L.). Revista Brasileira de Sementes, 26(1), 98-103. https://doi.org/10.1590/ S0101-31222004000100015

Ribeiro, F. C., \& Carvalho, N. M. de. (2005). The saturated salt accelerated ageing (SSAA) method seems to act too leniently on carrot (Daucus carota L.), lettuce (Lactuca sativa L.), and broccoli (Brassica oleracea var. italic Plenck) seeds germination. Cientifica, 33(2), 208-212.

Santos, F., Trani, P. E., Medina, P. F., \& Parisi, J. J. D. (2011). Teste de envelhecimento acelerado para avaliação da qualidade de sementes de alface e almeirão. Revista Brasileira de Sementes, 33(2), 322-323. https://doi.org/10.1590/S0101-31222011000200015

Torres S. B., \& Marcos Filho, J. (2001). Teste de envelhecimento acelerado em sementes de maxixe (Cucumi sanguria L.). Revista Brasileira de Sementes, 23(2), 108-112. https://doi.org/10.17801/0101-3122/rbs. v23n2p108-112

Torres, S. B., \& Negreiros, M. Z. (2008). Envelhecimento acelerado em sementes de berinjela. Revista Brasileira de Sementes, 30(2), 209-213. https://doi.org/10.1590/S0101-31222008000200026

Tunes, L. M., Badinelli, P. G., Olivo, F., \& Barros, A. C. S. A. (2009). Teste de envelhecimento acelerado em cevada. Magistra, 21(2), 111-119.

Tunes, L. M., Pedroso, D. C., Gadotti, G. I., Muniz, M. F. B., Barros, A. C. S. A., \& Villela, F. A. (2013). Accelerated aging to assess parsley seed vigor. Horticultura Brasileira, 31(3), 457-460. https://doi.org/ $10.1590 / \mathrm{S} 0102-05362013000300018$

Weber, L. C., Amaral-Lopes, A. C., Souza, K. R. R., Andrade, P. P., Gomes, A. S., Weber, R. R., \& Nascimento, W. M. (2010). Produção e qualidade de sementes híbridas de berinjela em função do número de frutos por planta. Horticultura Brasileira, 28(2), S4315-S4318. https://doi.org/10.1590/S0102-05362013000300019

\section{Copyrights}

Copyright for this article is retained by the author (s), with first publication rights granted to the journal.

This is an open-access article distributed under the terms and conditions of the Creative Commons Attribution license (http://creativecommons.org/licenses/by/4.0/). 